\title{
Cytostatic, cytotoxic, and antibacterial activities of essential oil isolated from Citrus hystrix
}

\author{
Magdalena Borusiewicz ${ }^{\mathrm{a}, *}$, Danuta Trojanowska ${ }^{\mathrm{b}}$, Paulina Paluchowska ${ }^{\mathrm{b}}$, Zbigniew Janeczko ${ }^{\mathrm{a}}$, \\ Max W. Petitjean ${ }^{\mathrm{c}}$, Alicja Budak ${ }^{\mathrm{b}}$ \\ ${ }^{a}$ Department of Pharmacognosy, Faculty of Pharmacy, Jagiellonian University Medical College, \\ 9 Medyczna Street, 30-688 Krakow, Poland \\ b Department of Pharmaceutical Microbiology, Faculty of Pharmacy, \\ Jagiellonian University Medical College, 9 Medyczna Street, 30-688 Krakow, Poland \\ c Apipol Farma Japan KK, Futaba 4-13-12, Shinagawa-ku, Tokyo
}

*Corresponding author, e-mail: m.borusiewicz@uj.edu.pl

Received 10 Sep 2015

Accepted 28 Mar 2017

\begin{abstract}
The essential oil obtained from the peel of Citrus hystrix fruits is a colourless or light yellow liquid with a strong citrus scent. It was analysed for its constituents using gas chromatography/mass spectroscopy. The major components of the oil were $\beta$-pinene, limonene, terpinen-4-ol, $\alpha$-pinene, $\alpha$-terpinene, $\gamma$-terpinene, and $\alpha$-terpineol. The antibacterial activity of $C$. hystrix essential oil was tested by disc diffusion and serial macrodilution methods against 50 multidrug-resistant Acinetobacter baumannii strains. The results confirmed its good activity expressed by minimal inhibitory concentration values in the range of $0.125-1 \mu \mathrm{l} / \mathrm{ml}$. The effect on the viability and proliferation of normal human skin fibroblasts (HSF) and the human melanoma cells (WM793 and A375) was also examined. The observed cytostatic and cytotoxic activities were dependent on the dose of tested oil and the incubation time. Melanoma cells (WM793 and A375) were more sensitive to the essential oil from C. hystrix peel than normal cells (HSF). These results suggest a need for more detailed research on its possible use in therapy.
\end{abstract}

KEYWORDS: Acinetobacter baumannii, cytotoxicity, cell proliferation, fibroblasts, melanoma

\section{INTRODUCTION}

The plant world is an inexhaustible source of various natural ingredients. Essential oils are complex natural mixtures of chemical compounds that may contain more than 300 components in various concentrations. These can be synthesized in all plant organs, i.e., buds, flowers, leaves, stems, branches, seeds, fruits, roots, wood, or bark, and are stored in secretory cells cavities, ducts, glands or epidermal cells ${ }^{1}$. The composition of essential oil is dependent on family, genus, and species to which it belongs, as well as the growth conditions, time of harvesting, and origin. The dynamic development of modern analytical methods, among others gas chromatography (GC) and mass spectroscopy (MS), undoubtedly contributed to the renewed interest in the medicinal properties of essential oils allowing to precisely determine the composition of these complex mixtures of plant compounds.

There is a considerable number of scientific reports documenting a variety of biological activities of different essential oils from various plant sources.
The use of essential oils from edible and medicinal plants, herbs, and spices still presents a curious case, since they constitute a class of potent natural antimicrobial agents. Their inclusion in food systems may be considered as an additional constitutional element to prevent the growth of pathogens, such as Listeria monocytogenes, Salmonella enterica, Escherichia coli, Staphylococcus spp., and Aspergillus niger $^{2,3}$. Similarly, nutritional agents (fruits, vegetables, spices, etc.) have attracted considerable research interest due to their ability to inhibit cell proliferation and, thus, reduce cancer progression ${ }^{4}$. Essential oils are considered promising substances for investigation of this therapeutic goal, as they appear to contain interesting dietary phytochemicals capable of suppressing the initiation of carcinogenesis, cellular hyperproliferation, inflammatory processes, and malignant transformation ${ }^{5}$.

Citrus hystrix DC. (first mentioned at Cat. Pl. Hort. Bot. Montp. 97 in 1813) ${ }^{6}$, also known as kaffir lime or makrut lime, is a common edible herb species of the Rutaceae family, that can be found in tropical Asian countries, such as Thailand, 
Indonesia, Malaysia, Vietnam, and Laos. Besides playing an important role in the South Eastern Asian cuisine, the essential oils from the leaves and the fruits are used commercially in Malaysia as flavour and fragrance agents, in perfumery and medicinal preparation ${ }^{3}$. C. hystrix is a small tree reaching 3-6 m high, often not straight but crooked, with glabrous and spiny branches bearing aromatic leaves and dark green fruits with irregular bumpy surface. The valued parts of the plant are leaves and fruit peel. C. hystrix fruit is about the size of western lime. It is dark green and round, with a distinct nipple on the stem end. It has a thick rind, knobby and wrinkled. As the fruit becomes older, the colour fades to a lighter, yellowish green ${ }^{7}$. The essential oil isolated from the makrut lime peel is a colourless or light yellow liquid with an intense, fresh, citruslike scent. The chemical composition of essential oil is well known. According to numerous studies conducted by independent research groups the main components of the oil are $\beta$-pinene, limonene, and terpinen-4-ol ${ }^{8,9}$.

Acinetobacter baumannii is one of the most important causative agent of healthcare-associated infections worldwide, including pneumonia (mainly ventilator-associated), bloodstream infections, urinary tract infections, wound infections as well as meningitis. Due to its low nutritional needs and ability to survive in a wide range of temperature and $\mathrm{pH}$ conditions, it has contaminated the hospital environment as well as medical equipment. The nosocomial A. baumannii infections affects particularly immunocompromised intensive care unit patients with severe underlying diseases, receiving numerous therapeutic and diagnostic invasive procedures $^{10}$.

Presently, 34 species belonging to the Acinetobacter genus have been described. While the A. calcoaceticus-A. baumannii complex consisted of four genospecies: A. calcoaceticus (genospecies 1), A. baumannii (genospecies 2), A. pittii (genospecies 3 ), and A. nosocomialis (genospecies 13TU), A. baumannii is predominantly found isolate in nosocomial infections. As a result, it has emerged as the most clinically relevant genospecies. Unfortunately, the routinely performed phenotypic methods cannot properly differentiate the species within the A. calcoaceticus-A. baumannii complex. For this purpose the application of molecular methods is required ${ }^{11,12}$.

Another disturbing problem is the growing antimicrobial resistance among $A$. baumannii isolates, making management, control, and treatment of infections more and more difficult. As a consequence of its high genome plasticity, this bacterium possesses the phenomenal ability to acquire foreign resistance determinants and up-regulate innate mechanisms of resistance. It resulted in an increasing rates of isolation of multidrug-resistant (MDR), extensively drug-resistant (XDR), or lately even pandrug-resistant $A$. baumannii strains ${ }^{12}$. MDR isolates were defined as possessing acquired nonsusceptibility to no less than one agent in three or more antimicrobial groups ${ }^{13}$. MDR A. baumannii infections are characterized by high morbidity and mortality rates among infected patients, increase the costs of therapy and are considered as major challenge for nowadays health assurance systems. Currently, when treatment options for combating those infections are extremely limited; and as an increasing resistance of many pathogenic bacteria to presently known antimicrobials has become a serious problem, there is a need to find alternative plant derived agents.

There are suggestions that the essential oils of C. hystrix, due to their terpene components, can be considered as potential antimicrobials, even against strains resistant to traditionally used medications. For years, many research groups have concentrated on the search for methods to maintain food safety from pathogens, which are the leading causes of infection of food. Apart from antimicrobial activity studies, also tumour cell growth inhibition was examined and compared for oils isolated from fruit peel and leaves of the makrut lime. Essential oils enter the body primarily in three ways-after they are applied to the skin, inhaled, or ingested. Due to their excellent penetration via skin, topical application is one of the most often used methods ${ }^{14}$. For that reason in the present study we decided to examine the effect of makrut lime oil on human skin fibroblasts (HSF), and two types of melanoma (WM73 and A375). Antiproliferative and cytotoxic activities were seen on tumour cells of P388 murine leukaemia and human nasopharyngeal cavity cancer KB. The oil from the peel, turned out to be more effective and thus has been assigned to a group of potential candidates for further research on antitumour substances ${ }^{15}$. According to these reports, the effect of this oil on the human cells justifies its use in therapy. The main objectives of the present study were to investigate the chemical composition of essential oil, to confirm the antibacterial activity against 50 strains of $A$. baumannii as well as to evaluate the influence on human normal and cancer cells. 


\section{MATERIALS AND METHODS}

\section{Plant material}

In the present study an essential oil obtained from Apipol Farma Japan was used. Fruits from which pure essential oil was isolated were obtained from their own plantations in the north-west Thailand, near the Nang Rong District. Fruits were collected from more than 30 years old trees after the rainy season in May 2013. A voucher specimen has been prepared and identified by botanist Agnieszka Szewczyk from the Department of Pharmaceutical Botany of Jagiellonian University Medical College and deposited at Department of Pharmacognosy, Faculty of Pharmacy, Jagiellonian University Medical College under Accession No. KFg/2014/1603.

\section{Distillation}

The extraction of essential oil was carried out by steam distillation with Clevenger-type apparatus. The duration of distillation process was $3 \mathrm{~h}$ at $110^{\circ} \mathrm{C}$ according to the method recommended in the European pharmacopoeia. The amount of volatiles from the $80 \mathrm{~kg}$ of extracted makrut lime peel was $1.10 \mathrm{~kg}$ (yield $=1 \%$ ). The essential oil from raw materials gave a pale yellow liquid and it was stored at $4{ }^{\circ} \mathrm{C}$ in a brown vial.

\section{Chemical composition}

This part of research was commissioned to Central Laboratory of the Agroecology, University of Life Sciences in Lublin. The chemical composition was examined by GC/MS method. A highly sensitive and accurate multiplex gas chromatography-linear ion trap technique was used to identify components of the volatiles. GC/MS/MS was performed using Varian 4000 GC/MS/MS chromatograph equipped with Flame Ionization Detector. The GC conditions were as follows. VF-5 ms fused silica capillary column (30 m $\times 0.25 \mathrm{~mm}$, film thickness $0.25 \mu \mathrm{m})$, the oven temperature was programmed at a rate of $1^{\circ} \mathrm{C}$ from 50 (held for $5 \mathrm{~min}$ ) to $250{ }^{\circ} \mathrm{C}$, injector and detector kept at $250^{\circ} \mathrm{C}$, split ratio 1:100. Helium was used as the carrier gas with a constant flow rate of $0.5 \mathrm{ml} / \mathrm{min}$. The volume of injection was $1 \mu 1$ of a pentane-volatile solution (1:1). Mass spectra were recorded at $70 \mathrm{eV}$. Mass range was from $m / z 40-1000$. The identification of individual compounds resulted on the basis of Kovats linear retention index determination relative to (C6-C40) $n$-alkanes and retention time. Compounds were further identified using their MS data compared to a home-made library mass spectra built up from pure substances (Main Lab Library) and with mass spectra literature data ${ }^{16}$.

\section{Bacterial strains}

The antibacterial activity of $C$. hystrix peel essential oil was tested against a total of 49 clinical A. baumannii strains, isolated from individuals hospitalized in Ludwik Rydygier Memorial Specialized Hospital in Cracow, Poland, between 2009 and 2013. The vast majority of strains were recovered from patients of Intensive Care (31 strains, 63\%) and Burn Therapy (14 strains, 29\%) units, from various specimens, including: endotracheal aspirate (ETA) (18 strains, 37\%), blood samples (17 strains, 35\%), wound swab ( 8 strains, 16\%), urine (4 strains, 8\%), and CVP catheter (2 strains, 4\%) (Table 1). Acinetobacter baumannii 19606 from American Type Culture Collection (ATCC) was used as the reference strain in the identification methods as well as in assessment of $C$. hystrix oil antibacterial activity.

\section{Acinetobacter baumannii strains identification and antimicrobial susceptibility testing}

Phenotypic identification of isolates was conducted with Vitek-2 Compact system and ID GN cards (bioMérieux, Marcy l'Etoile, France). Susceptibility testing, concerning minimal inhibitory concentration (MIC), regarding routinely used antibacterial agents, such as imipenem (IMP), meropenem (MEM), amikacin (AK), gentamicin (CN), tobramycin (TOB), ciprofloxacin (CIP), colistin (COL), and trimethoprim/sulphamethoxazole (SXT), were performed using Vitek-2 Compact system and relevant antimicrobial susceptibility testing cards (bioMérieux, Marcy l'Etoile, France). Obtained results were interpreted according to Clinical Laboratory Standards Institute criteria ${ }^{17}$.

Due to the difficulties in distinguishing between Acinetobacter genospecies, the phenotypic identification of analysed isolates was confirmed with molecular method by amplification of a 353-bp fragment of genes encoding OXA-51-like $\beta$-lactamases, intrinsic to $A$. baumannii. The bacterial DNA was extracted using the Genomic Mini isolation kit (A\&A Biotechnology, Poland) according to the manufacturer's recommendations. The PCR reaction was carried out as described previously by Woodford et $\mathrm{al}^{18}$.

The identified A. baumannii isolates were stored in Tryptic soy broth (TSB, Becton Dickinson and Company, Le Pont de Claix, France) with glycerol (v/v 10\%) at $-80^{\circ} \mathrm{C}$ for further analyses. 
Table 1 Antimicrobial activity of Citrus hystrix peel essential oil against 50 Acinetobacter baumannii strains assessed by disc diffusion and broth macrodilution methods.

\begin{tabular}{|c|c|c|c|c|c|c|}
\hline \multirow[t]{2}{*}{ No. } & \multirow[t]{2}{*}{$\begin{array}{l}\text { Number of } \\
\text { strain }\end{array}$} & \multirow[t]{2}{*}{$\begin{array}{l}\text { Clinical } \\
\text { material }\end{array}$} & \multicolumn{3}{|c|}{$\begin{array}{l}\text { Zone of inhibition (mm) } \\
\text { at oil concentration of }\end{array}$} & \multirow[t]{2}{*}{$\begin{array}{c}\mathrm{MIC} \\
(\mu \mathrm{l} / \mathrm{ml})\end{array}$} \\
\hline & & & $100 \%$ & $50 \%$ & $25 \%$ & \\
\hline 1 & ATCC 19606 & urine & 23 & 16 & 15 & 0.125 \\
\hline 2 & $4309 / 1 / 9$ & ETA & 20 & 14 & 13 & 1 \\
\hline 3 & $4391 / 1 / 9$ & ETA & 17 & 14 & 11 & 1 \\
\hline 4 & $4456 / 1 / 9$ & wound swab & 21 & 14 & 12 & 0.5 \\
\hline 5 & $53 / 1 / 10$ & CVP catheter & 20 & 14 & 10 & 0.25 \\
\hline 6 & $119 / 2 / 10$ & wound swab & 21 & 15 & 11 & 0.5 \\
\hline 7 & $302 / 1 / 10$ & ETA & 20 & 13 & 11 & 0.5 \\
\hline 8 & $376 / 2 / 10$ & wound swab & 22 & 14 & 11 & 0.25 \\
\hline 9 & $804 / 2 / 11$ & ETA & 18 & 14 & 11 & 0.5 \\
\hline 10 & $911 / 2 / 11$ & ETA & 18 & 13 & 12 & 0.5 \\
\hline 11 & $1170 / 2 / 11$ & ETA & 24 & 17 & 15 & 0.125 \\
\hline 12 & $1212 / 11$ & wound swab & 20 & 12 & 10 & 1 \\
\hline 13 & $1740 / 11$ & ETA & 18 & 11 & 7 & 1 \\
\hline 14 & $1755 / 11$ & wound swab & 18 & 14 & 13 & 0.5 \\
\hline 15 & $176 / 3 / 12$ & ETA & 16 & 13 & 10 & 1 \\
\hline 16 & $532 / 1 / 12$ & ETA & 18 & 11 & 10 & 0.5 \\
\hline 17 & $534 / 1 / 12$ & ETA & 15 & 12 & 10 & 1 \\
\hline 18 & $1354 / 12$ & urine & 18 & 13 & 11 & 0.5 \\
\hline 19 & $3621 / 12$ & blood & 15 & 11 & 9 & 1 \\
\hline 20 & $3628 / 12$ & blood & 19 & 16 & 14 & 1 \\
\hline 21 & $3813 / 12$ & blood & 18 & 11 & 9 & 1 \\
\hline 22 & $3821 / 12$ & blood & 18 & 13 & 11 & 0.5 \\
\hline 23 & $4443 / 12$ & blood & 19 & 16 & 10 & 0.5 \\
\hline 24 & $142 / 13$ & blood & 18 & 15 & 11 & 0.5 \\
\hline 25 & $157 / 13$ & urine & 16 & 14 & 11 & 0.5 \\
\hline 26 & $248 / 13$ & blood & 16 & 13 & 11 & 0.25 \\
\hline 27 & $309 / 13$ & blood & 16 & 13 & 10 & 0.5 \\
\hline 28 & $449 / 13$ & blood & 18 & 14 & 11 & 0.25 \\
\hline 29 & $1668 / 13$ & urine & 20 & 19 & 14 & 0.5 \\
\hline 30 & $1673 / 13$ & urine & 17 & 11 & 8 & 1 \\
\hline 31 & $3049 / 13$ & ETA & 17 & 15 & 11 & 1 \\
\hline 32 & $3060 / 13$ & ETA & 20 & 16 & 13 & 0.25 \\
\hline 33 & $3068 / 13$ & ETA & 17 & 15 & 11 & 1 \\
\hline 34 & $3129 / 13$ & ETA & 16 & 15 & 12 & 1 \\
\hline 35 & $3225 / 13$ & wound swab & 20 & 14 & 10 & 1 \\
\hline 36 & $3230 / 13$ & ETA & 18 & 15 & 13 & 0.5 \\
\hline 37 & $3232 / 13$ & ETA & 19 & 13 & 9 & 0.5 \\
\hline 38 & $3292 / 13$ & ETA & 20 & 16 & 12 & 0.5 \\
\hline 39 & $3294 / 13$ & wound swab & 19 & 12 & 10 & 0.5 \\
\hline 40 & $3322 / 13$ & blood & 24 & 15 & 14 & 0.25 \\
\hline 41 & $3325 / 13$ & wound swab & 20 & 18 & 14 & 0.125 \\
\hline 42 & $3332 / 13$ & ETA & 17 & 11 & 7 & 1 \\
\hline 43 & $3335 / 13$ & CVP catheter & 17 & 12 & 9 & 1 \\
\hline 44 & $3355 / 13$ & blood & 24 & 15 & 14 & 0.25 \\
\hline 45 & $3363 / 13$ & blood & 19 & 13 & 8 & 0.5 \\
\hline 46 & $3367 / 13$ & blood & 19 & 13 & 9 & 0.5 \\
\hline 47 & $3394 / 13$ & blood & 20 & 13 & 10 & 0.25 \\
\hline 48 & $3854 / 13$ & blood & 16 & 10 & 7 & 1 \\
\hline 49 & $4018 / 13$ & blood & 18 & 12 & 9 & 0.5 \\
\hline \multirow[t]{2}{*}{50} & $4145 / 13$ & blood & 19 & 12 & 9 & 0.5 \\
\hline & Range & & $15-24$ & $10-19$ & $7-15$ & $0.125-1$ \\
\hline
\end{tabular}

Prior to testing, each isolate was inoculated onto Trypcase soy agar (bioMérieux, Marcy l'Etoile, France) and incubated aerobically at $37^{\circ} \mathrm{C}$ for $24 \mathrm{~h}$.

\section{Determination of antibacterial activity of C. hystrix essential oil}

Antibacterial activity of $C$. hystrix peel essential oil was determined by disc diffusion method ${ }^{19}$, as a preliminary screening test prior to quantitative MIC determination with dilution method.

Stock solutions were prepared by dissolving the C. hystrix peel essential oil in 100\% dimethyl sulphoxide (DMSO; Sigma-Aldrich, Germany), to obtain following concentrations of oil: 50\%, 25\% as well as $12.5 \%$. Undiluted C. hystrix oil was also tested. Discs impregnated with DMSO at concentrations used in the dilution of oil served as control. In the performed experiment, discs containing only DMSO did not inhibit bacterial growth.

Bacterial inoculum was prepared from overnight cultures by measuring in a densitometer at $600 \mathrm{~nm}$ to adjust to an optical density of 0.5 McFarland units (approximately $1 \times 10^{8}$ colony forming units $/ \mathrm{ml}$ ). A sterile cotton swab was dipped into the suspension and then the inoculum was spread over the surface of the Mueller-Hinton agar (bioMérieux, Marcy l'Étoile, France) on $90 \mathrm{~mm}$-diameter Petri dishes, by swabbing in three directions. Next, the sterile paper discs $(6 \mathrm{~mm}$ in diameter; Oxoid Ltd, Hampshire, UK) were placed on the surface of agar plate and impregnated with $15 \mu \mathrm{l}$ of the each concentration of $C$. hystrix oil. Plates were incubated aerobically at $37^{\circ} \mathrm{C}$ for $24 \mathrm{~h}$. The zones of inhibition of bacterial growth were measured in millimetres. The eight $\mathrm{mm}$ zone diameter was taken as the lowest oil activity.

Minimal inhibitory concentrations of oil were determined with the broth macrodilution method, according to the National Committee for Clinical Laboratory Standards with modifications ${ }^{20}$. The stock solution was prepared as follows: $32 \mu \mathrm{l}$ of C. hystrix oil was dissolved in $168 \mu \mathrm{l}$ of DMSO and then supplemented with an amount of $1.8 \mathrm{ml}$ of TSB to obtain a final oil concentration of $16 \mu \mathrm{l} / \mathrm{ml}$. Next, two-fold serial dilutions in test tubes, each containing $1 \mathrm{ml}$ of TSB, were prepared to receive the concentrations of $C$. hystrix peel oil ranging from $0.0625 \mu \mathrm{l} / \mathrm{ml}$ to $8 \mu \mathrm{l} / \mathrm{ml}$. Bacterial inoculum was prepared as in disc diffusion method and $100 \mu \mathrm{l}$ of suspension (approximately $1 \times 10^{7} \mathrm{CFU} / \mathrm{ml}$ ) was added to each test tube. A sterile TSB without oil served as control for bacterial growth. Negative control tubes contain a TSB medium only. Control media containing DMSO at concentrations (from $0.03 \%$ to $8 \%$ ), used in the dilution of oil, did not inhibit bacterial growth. Incubation was performed for $24 \mathrm{~h}$ at $35^{\circ} \mathrm{C}$ and the MIC was determined as the lowest oil concentration inhibiting visible bacterial growth.

\section{Cells and cell culture}

Human skin fibroblasts-HSF cell line, melanoma cell lines A375 (ATCC), and WM793 (ESTDAB)were used in this study. HSF cells were isolated from skin obtained from plastic surgery and cultured at Department of Cell Biology, Fac- 
ulty of Biochemistry, Biophysics, and Biotechnology, Jagiellonian University, Krakow, Poland. The study was performed in compliance with ethical protocols KBET/72/B/2008 approved by Jagiellonian University Institutional Bioethics Committee. The cells were routinely cultured in DMEM with $1000 \mathrm{mg}$ glucose/1 medium (HSF), DMEM with $4500 \mathrm{mg}$ glucose/1 (A375), and DMEM-F12 HAM medium (WM793), each supplemented with $10 \%$ FBS (foetal bovine serum) and antibiotics (penicillin-streptomycin), (all from Sigma-Aldrich, USA) in standard conditions $\left(37^{\circ} \mathrm{C}, 5 \% \mathrm{CO}_{2}\right)$.

\section{Preparation of oil samples}

Cells were incubated with three different concentrations of essential oil: $0.05 \mathrm{mg} / \mathrm{ml}, 0.1 \mathrm{mg} / \mathrm{ml}$, and $0.15 \mathrm{mg} / \mathrm{ml}$. The final volume in each experiment was made up to $1 \mathrm{ml}$ for proliferation assay and $0.5 \mathrm{ml}$ for viability assay with media containing less than $0.01 \%$ of ethanol. At this concentration ethanol did not exert any effect on HSF, WM793, and A375 cells proliferation or viability (data not shown).

\section{Proliferation assay}

For proliferation tests, cells were seeded in the culture medium supplemented with 10\% FBS into 12-well plates (TPP) at an initial density of $5 \times 10^{3}$ cells $/ \mathrm{cm}^{2}$ (HSF) and $4.5 \times 10^{3}$ cells $/ \mathrm{cm}^{2}$ (WM793 and A375) and incubated for $24 \mathrm{~h}$ at $37^{\circ} \mathrm{C}$. Then, the medium was replaced with a fresh one without (vehicle control) or with oil, respectively, at the concentrations: $0.05 \mathrm{mg} / \mathrm{ml}, 0.1 \mathrm{mg} / \mathrm{ml}$, and $0.15 \mathrm{mg} / \mathrm{ml}$. The cells were harvested by trypsinization every $24 \mathrm{~h}$ for 3 days and their numbers were counted using a cell counter (Bürker haemocytometer). Three independent experiments were performed for each condition.

\section{Viability (cytotoxicity) assay}

For viability tests, cells were seeded into 24-well plates (TPP) and incubated for $24 \mathrm{~h}$ at $37^{\circ} \mathrm{C}$, in the same way as described for the proliferation assay. Then, the medium was replaced with a fresh one without (vehicle control) or with oil, respectively, at the concentrations: $0.05 \mathrm{mg} / \mathrm{ml}, 0.1 \mathrm{mg} / \mathrm{ml}$, and $0.15 \mathrm{mg} / \mathrm{ml}$. Cell viability was determined by LDH test, colorimetric assay (using LDH Cytotoxicity Detection Kit, Clonetech Laboratories, Inc.) and the trypan blue (Sigma-Aldrich, USA) assay. In the LDH test, the measurements were carried out with the computer program GEN5 and the scanning hardware Synergy HT Biotek. Absorbance of the samples was measured at $492 \mathrm{~nm}$ and the reference wavelength was $600 \mathrm{~nm}^{21}$. In the trypan blue test, the measurements were carried out under the microscope, where 100 cells were counted in each experiment by the percentage of viable cells ${ }^{22}$. Three independent experiments were performed for each condition.

\section{RESULTS AND DISCUSSION}

\section{Chemical composition of the $C$. hystrix peel essential oil}

Conferring to several studies conducted by independent research groups the main components of the oil isolated from Thai $C$. hystrix are $\beta$-pinene and limonene ${ }^{8,9}$. From the findings, the major constituents of examined C. hystrix peel essential oil were limonene (26\%), $\beta$-pinene $(17 \%)$, and terpinen-4-ol (10\%). Other minor components were $\alpha$-terpineol (9\%), $\gamma$-terpinene (6\%), terpinolene (4\%), and $\alpha$-terpinene (4\%). The results obtained from the GC/MS analysis are illustrated in Table 2. The major constituents of makrut lime oils originated from Thailand agreed that three abundance compounds in makrut lime peel oil are limonene, $\beta$-pinene, and terpinen-4-ol ${ }^{23}$, but results received from fruits do not confirm that compatibility. Another study by Sutthanont et $\mathrm{al}^{24}$ also confirmed the presence of these compounds in oil originated from fruit peels from Thailand, whereas Malaysian fruits oil primarily consists of sabinene $(35 \%)^{25}$. Generally, the quality of makrut lime peel oil is comparable to that of other regions of Thailand where the major compounds have been detected, with only slight differences in the percentage of its concentrations. Thus the quality of essential oil in this experiment can be acceptable. The differences in the oil composition of $C$. hystrix from distinct sources, probably attributed to different response to environment conditions as well as distillation method, strongly support for the need for a thorough evaluation of the biological properties of these oils obtained from different locations.

\section{Antibacterial activity of $C$. hystrix peel essential oil against $A$. baumannii}

Phenotypic identification of $A$. baumannii clinical strains was confirmed in all isolates by the presence of $b l a_{\text {OXA-51-like }}$ genes (data not shown). Moreover, based on the antimicrobial susceptibility testing, we concluded that conventional antibiotics were mostly not efficient against tested isolates (Fig. 1). Consequently, according to criteria accepted by a group of 
Table 2 Chemical composition of the essential oil from Citrus hystrix peel obtained from GC/MS analysis.

\begin{tabular}{|c|c|c|}
\hline Component & $\mathrm{RI}_{\text {exp }}$ & Research results (\%) \\
\hline$\alpha$-thujene & 979 & 0.19 \\
\hline$\alpha$-pinene & 981 & 3.59 \\
\hline camphene & 986 & 0.78 \\
\hline sabinene & 993 & 1.59 \\
\hline$\beta$-pinene & 995 & 17.40 \\
\hline myrcene & 997 & 1.77 \\
\hline$\alpha$-phellandrene & 1009 & 1.06 \\
\hline carene & 1011 & absent \\
\hline cineole $(1,4)$ & 1017 & 0.83 \\
\hline cineole $(1,8)$ & & absent \\
\hline$\alpha$-terpinene & 1019 & 4.32 \\
\hline p-cymene & 1026 & 1.95 \\
\hline limonene & 1032 & 26.33 \\
\hline$\gamma$-terpinene & 1059 & 6.43 \\
\hline cis-linalool oxide & 1070 & 1.32 \\
\hline terpinolene & 1085 & 4.45 \\
\hline linalool & 1097 & 0.43 \\
\hline fenchol & 1121 & 0.49 \\
\hline citronellal & 1148 & absent \\
\hline isopulegol & 1152 & 2.09 \\
\hline iso-isopulegol & 1163 & 1.39 \\
\hline borneol & 1178 & 0.44 \\
\hline terpinen-4-ol & 1186 & 10.20 \\
\hline$\alpha$-terpineol & 1201 & 8.76 \\
\hline citronellol & 1230 & 0.44 \\
\hline citronellyl acetate & 1353 & 0.28 \\
\hline$\alpha$-cubebene & 1372 & $\operatorname{tr}$ \\
\hline geranyl acetate & 1381 & 0.20 \\
\hline$\alpha$-copaene & 1385 & 0.35 \\
\hline caryophyllene & 1433 & 0.19 \\
\hline$\delta$-amorphene & 1534 & 0.57 \\
\hline$\gamma$-cadinene & 1539 & $\operatorname{tr}$ \\
\hline Total & & 97.84 \\
\hline
\end{tabular}

$\operatorname{tr}=$ peak area $<0.1 \%$

international experts ${ }^{13}$, all strains analysed in the present study were multidrug-resistant. The only antimicrobial drug, which has retained its efficacy against $A$. baumannii was colistin, with $100 \%$ susceptible isolates, while ciprofloxacin presented no activity against MDR isolates.

In the preliminary microbiological studies, we have evaluated antibacterial activity of $C$. hystrix essential oil against MDR A. baumannii strains by disc diffusion method. The diameter of inhibition zones obtained for reference strain ATCC 19606 around the discs soaked with the $C$. hystrix oil at concentrations of $25 \%, 50 \%$, and $100 \%$ were $15 \mathrm{~mm}, 16 \mathrm{~mm}$, and $23 \mathrm{~mm}$, respectively. Furthermore, makrut lime oil exhibited the diameter of inhibition zones

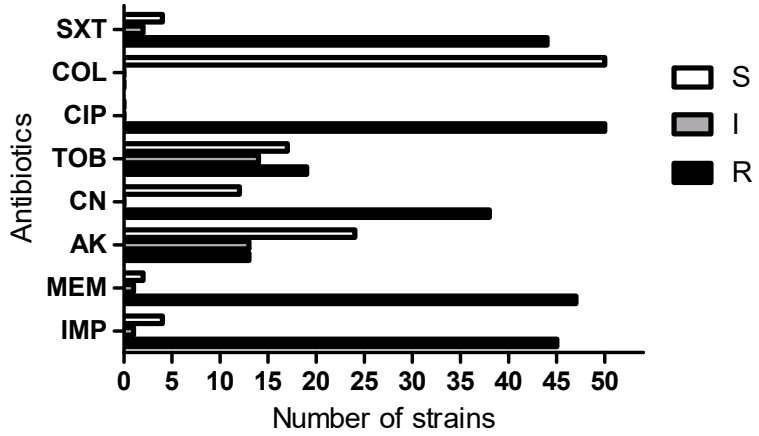

Fig. 1 Susceptibility of Acinetobacter baumannii clinical isolates to: imipenem (IMP), meropenem (MEM), amikacin (AK), gentamicin (CN), tobramycin (TOB), ciprofloxacin (CIP), colistin (COL), and trimethoprim/sulphamethoxazole (SXT). S: susceptible; I: intermediate; R: resistant.

towards clinical A. baumannii isolates, as follows: 7-15 mm for $25 \%$ oil concentration, $10-19 \mathrm{~mm}$ for $50 \%$ oil concentration, and $15-24 \mathrm{~mm}$ for $100 \%$ (Table 1). The $12 \%$ oil concentration was not active.

The MIC values $(\mu \mathrm{l} / \mathrm{ml})$ of $C$. hystrix oil determined by macrodilution method varied among tested MDR A. baumannii strains. In general, makrut lime oil was effective against analysed bacteria with MIC values in the range from $0.125-1 \mu \mathrm{l} / \mathrm{ml}$, with a median $0.5 \mu \mathrm{l} / \mathrm{ml}$. More precisely, the MIC value of $0.125 \mu \mathrm{l} / \mathrm{ml}$ was obtained versus 3 strains (6\%), $0.25 \mu \mathrm{l} / \mathrm{ml}$ against 8 strains (16\%), $0.5 \mu \mathrm{l} / \mathrm{ml}$ versus 22 strains (45\%), and $1 \mu \mathrm{l} / \mathrm{ml}$ against 17 strains (35\%). Both the most susceptible clinical isolates (no 1170/2/11 from ETA and no 3325/13 from wound swab) were recovered from patients of intensive care units. The data presented herein show good antimicrobial activity of $C$. hystrix oil against this type of bacterium.

Moreover, the obtained MIC values may be linked with characteristics of the main components included in the essential oil from the makrut lime fruit peel, that is $\beta$-pinene, limonene, terpinen-4ol, and $\alpha$-terpineol. Srisukh et $\mathrm{al}^{8}$ investigated the effect of the individual compounds included in the essential oil and concluded that $\alpha$-terpineol and terpinen-4-ol were more active than the entire mixture of compounds, however limonene, which is the main component of this essential oil, when used separately, showed significantly less activity against A. baumannii. Nevertheless, further research should be carried out to test the potential use of this oil in therapy.

Despite the significant advances in medicine 
concerning diagnosis and treatment strategies observed in recent decades, the number of lifethreatening infections is rising. The predominant bacterial species involved in nosocomial infections are Klebsiella pneumoniae, methicillin-resistant Staphylococcus aureus, Pseudomonas aeruginosa, Escherichia coli, as well as A. baumannii. Presently, the emergence of resistance to antimicrobial agents increased rapidly and extended worldwide, inter alia among abovementioned species, constitutes a fundamental threat to public health. In the light of those facts, it seems to be necessary and even mandatory to undertake and continue research concerning searching for new potential antimicrobial agents. While contemporary medicine is still looking for new methods of treating a number of infectious diseases, the analyses of antimicrobial properties of essential oils extracted from different plants could be a crucial step in this process.

The biological activity of citrus essential oils is constantly subject of numerous in vitro and in vivo studies. Those oils and their terpene components can be considered as potential antimicrobials, even against microorganisms resistant to traditionally used drugs. An important advantage of essential oils is the lack of development of resistance among bacteria ${ }^{26}$. The compounds included in the essential oils, highly lipophilic substances, readily pass through the cell membrane of various microorganisms causing an alteration in the integrity of its structure. Literature studies show few likely mechanisms of toxicity to bacteria. One of them may be coagulation of cytoplasm ${ }^{27}$ or permeabilization of the cell membrane, which results in excessive loss of ions and lowering the membrane potential which in turn disrupts the proton pump and the related reduction in intracellular $\mathrm{ATP}^{28-30}$. These promising results of in vitro studies justify the need to conduct further analysis to confirm potential in vivo efficacy and to assess possible adverse effects, which would consequently enable the use of essential oils in the prevention and treatment on a much broader scale.

The present study revealed good antibacterial activity of $C$. hystrix peel oil versus clinical MDR A. baumannii strains, both in disc diffusion and broth macrodilution method. There are some reports concerning activity of makrut lime oil against Gram-negative bacilli of $A$. baumannii species. Srisukh et $\mathrm{al}^{8}$ compared the activity of oils extracted from the leaves and fruit peel of C. hystrix against the pathogens of respiratory tract infections, which often are a major health problem. The effect was measured towards the clinical strains of A. baumannii, Streptococcus pneumoniae, Haemophilus influenzae, Moraxella catarrhalis, and $S$. aureus. Although the results confirmed the activity of both oils, particularly against $M$. catarrhalis, the oil of lime peel proved to be much more potent, being effective at significantly lower concentrations. The efficacy of leaves and peel $C$. hystrix oil versus A. baumannii revealed considerably higher MIC values than determined in our study $(2.10-17 \mathrm{mg} / \mathrm{ml}$ and $1.10-4.40 \mathrm{mg} / \mathrm{ml}$, respectively).

Moreover, many studies confirmed antimicrobial activity of makrut lime oils versus various microorganisms. While Wongsariya et $\mathrm{al}^{31}$ indicated high efficacy of $C$. hystrix leaves oil towards bacteria causing periodontal diseases, they conclude that oil extracted from fruit peel did not exhibit antibacterial potential. On the contrary, previous studies have reported the ability to inhibit the growth of Gram-positive bacteria ( $S$. aureus, Bacillus cereus, and L. monocytogenes), yeast (Saccharomyces cerevisiae), and moulds (Aspergillus fumigatus) by oil from C. hystrix peel ${ }^{32}$. Another interesting report on the impact of oil from the peel of makrut lime showed growth inhibition of nine serotypes of Salmonella (S. agon, S. anatum, S. aholeraesuis, S. derby, S. enteritidis, S. rissen, S. senftenberg, S. typhimurium, and S. typhimurium DT104) and four strains belonging to the Enterobacteriaceae family (including Citrobacter freundii, Enterobacter aerogenes, E. coli, and K. pneumoniae) ${ }^{33}$. Other studies confirmed the activity of oil against $B$. subtilis ATCC 6633, E. coli ATCC 25922, S. aureus ATCC 25923, and S. typhimurium ATCC $13311^{9}$. There are also reports showing that Propionibacterium acnes is susceptible to the essential oil from $C$. hystrix peel. The inhibition of bacterial colony growth was seen at the lowest concentration used $(0.25 \%)$, and the zone was widening with increasing concentrations. In the same study the anti-inflammatory activity of this essential oil was confirmed ${ }^{34}$.

In addition, there are scientific reports presenting other essential oils with antibacterial activity towards A. baumannii strains. Nevertheless, obtained MIC values were higher than in our experiments. According to Aleksic et $\mathrm{al}^{35}$, the promising alternative treatment of MDR A. baumannii infections seems to be Myrtus communis essential oil. Besides its effectiveness, when examined alone (MIC in the range from $0.25-4 \mu \mathrm{l} / \mathrm{ml}$ ), they presented synergistic activity in combination with conventional antibiotics (ciprofloxacin and polymyxin B). Another investigation also exhibited variable activity of different essential oil, including: cinnamon bark oil 

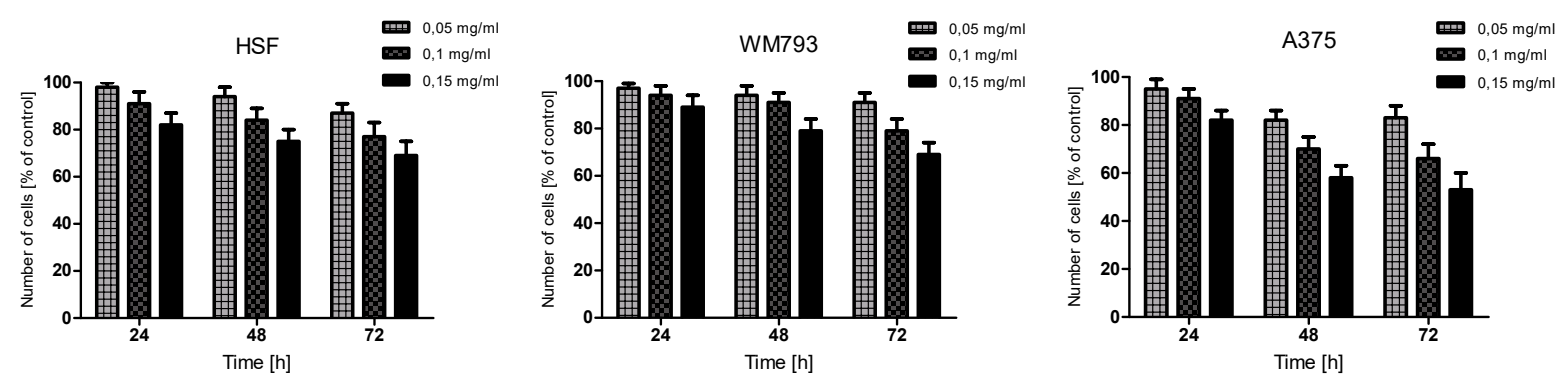

Fig. 2 Cytostatic effect of essential oil from Citrus hystrix peel on normal human skin fibroblasts (HSF) and melanoma cells (WM793 and A375). Cell numbers in oil-treated populations are expressed as the percent of vehicle control. Values represent means \pm SEM. Each experiment was done in triplicate.

(MIC from 0.5-2.5 $\mu \mathrm{l} / \mathrm{ml}$ ), geranium oil (MIC from 7.5-8.0 $\mu \mathrm{l} / \mathrm{ml}$ ), and lavender oil (MIC from 10.5$13.0 \mu \mathrm{l} / \mathrm{ml}$ ) towards A. baumannii clinical strains possessing considerable degree of antibiotic resistance ${ }^{36}$. Knezevic et $\mathrm{al}^{37}$ determined the in vitro antibacterial activity of Eucalyptus camaldulensis essential oils against twenty-three MDR strains of A. baumannii by using broth microdilution method, and obtained MIC values in the range $0.5-2 \mu \mathrm{l} / \mathrm{ml}$.

In conclusion, these results delivered promising data of potential use of $C$. hystrix peel essential oil in the treatment and eradication of MDR A. baumannii infection, nevertheless they require further analysis, especially regarding the synergistic activity of oils and conventional antibiotics.

Antiproliferative effect of the essential oil from the peel of $C$. hystrix on human skin fibroblasts and cancer melanoma cells cultured in vitro

Cell proliferation was examined in the presence of C. hystrix oil, which was added to the medium at concentrations of $0.05 \mathrm{mg} / \mathrm{ml}, 0.1 \mathrm{mg} / \mathrm{ml}$, and $0.15 \mathrm{mg} / \mathrm{ml}$. The results indicate that $C$. hystrix oil affected on cell proliferation of all tested cell lines at dose- and time-depended manner. A dosedependent inhibition was seen at concentrations between $0.1 \mathrm{mg} / \mathrm{ml}$ and $0.15 \mathrm{mg} / \mathrm{ml}$ (Fig. 2). At higher concentrations, the effect on cell proliferation was already visible after $24 \mathrm{~h}$ of incubation. It has been shown that melanoma cells were more sensitive than normal skin fibroblasts, for which $80 \%$ inhibition was observed after $72 \mathrm{~h}$ of incubation in comparison to cells cultured under control conditions in the absence of $C$. hystrix oil. At higher concentrations $(0.1 \mathrm{mg} / \mathrm{ml}$ and $0.15 \mathrm{mg} / \mathrm{ml})$, the tested oil inhibited melanoma cell proliferation to a higher extent. The most significant effect was visible after $72 \mathrm{~h}$, when cell proliferation was inhibited by 70\% (WM793) and 60\% (A375) in the highest tested concentration. It can be concluded that the cytostatic effect of the essential oil from $C$. hystrix peel significantly increases with the incubation time.

Cytotoxic effect of the essential oil from the peel of $C$. hystrix on human skin fibroblasts and cancer melanoma cells cultured in vitro

Cytotoxic effect of the essential oil from $C$. hystrix peel was examined at the concentration ranges of $0.05 \mathrm{mg} / \mathrm{ml}, 0.1 \mathrm{mg} / \mathrm{ml}$, and $0.15 \mathrm{mg} / \mathrm{ml}$. The average results obtained by two methods (LDH test and trypan blue assay) are shown in Fig. 3. The tested oil causes cytotoxic effect on normal and cancer cells, even at the lowest applied concentration. The results indicate that oil affects the viability of cells at dose- and time-depended manner, and melanoma cells (WM793 and A375) were found to be more sensitive than normal skin fibroblasts. In both type of cells, a decrease of cell viability was observed after $24 \mathrm{~h}$ of incubation over the whole concentration range. After first day of incubation with oil concentration of $0.15 \mathrm{mg} / \mathrm{ml}$, the number of living cells decreased by approximately 50\% (WM793) and 45\% (A375) in comparison to number of cells cultured under control conditions in the absence of $C$. hystrix oil. The extension of incubation time significantly increased the effect. After $72 \mathrm{~h}$, the number of living cells were almost 40\% (WM793) and 30\% (A375) at the highest tested concentration. As shown in Fig. 3, no cytotoxic effect was observed in HSF cells, except for the highest tested concentration $(0.15 \mathrm{mg} / \mathrm{ml})$, when the number of living cells decreased to approximately $80 \%$ after $24 \mathrm{~h}$ and $70 \%$ after 72 h. For both WM793 and A375 cells, at each concentration used, the percentage of viable cells after 24,48 , and $72 \mathrm{~h}$ of incubation apparently decreased. Similar results have not been observed with respect to the HSF cells.

This study presents an interesting analysis of 

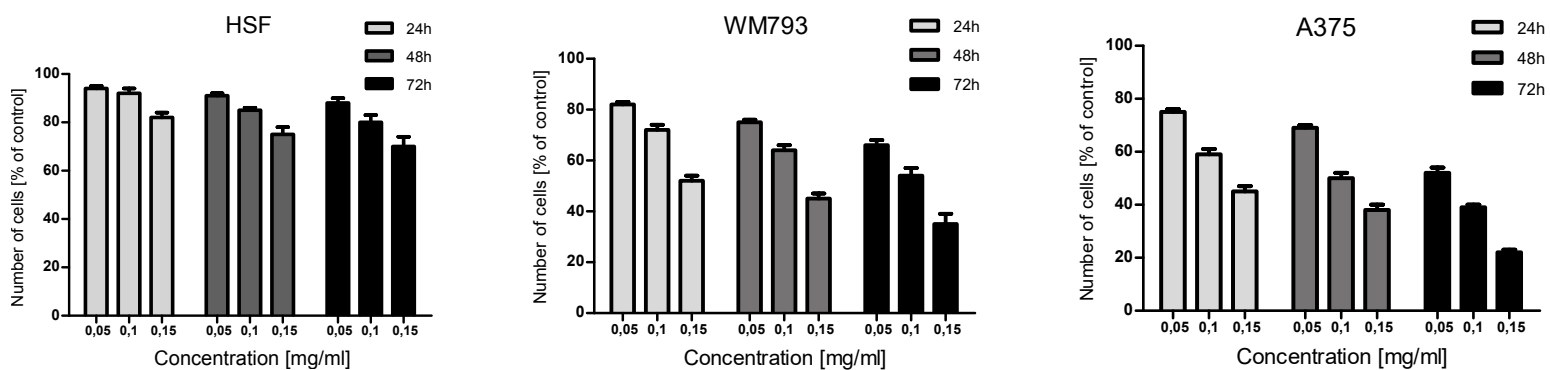

Fig. 3 Cytotoxic effect of essential oil from Citrus hystrix peel on normal human skin fibroblasts (HSF) and melanoma cells (WM793 and A375). Cell numbers in oil-treated populations are expressed as the percent of vehicle control. Values represent means \pm SEM. Each experiment was done in triplicate.

the chemical composition of essential oil of C. hystrix peel from Nang Rong District in Thailand. It presents also for the first time an antiproliferative and cytotoxic activity of the essential oil against melanoma cell line as well as normal skin fibroblasts. Literature reports concerning the effect of the essential oil from $C$. hystrix or its constituents on different cell lines are scarce. Growth inhibition of human breast cancer cell lines ${ }^{38}$ and antiproliferative activity and cytotoxic against tumour cells of P388 murine leukaemia and human cancer line nasopharyngeal KB have been proven ${ }^{15}$. The obtained results have demonstrated the inhibitory effect of the oil in the tested concentration range $(0.05 \mathrm{mg} / \mathrm{ml}$, $0.1 \mathrm{mg} / \mathrm{ml}$, and $0.15 \mathrm{mg} / \mathrm{ml}$ ). Especially interesting was the fact that both melanoma cell lines (WM793 and A375) were more susceptible to the effect of the essential oil from $C$. hystrix peel than normal cells such as human skin fibroblasts. Antiproliferative effects of oil may suggest its possible future use in the treatment of hyperproliferative skin disorders, however, it would be necessary to check to what extent the oil would inhibit the growth of other types of human skin cells, e.g., keratinocytes.

The molecular mechanisms involved in the antitumor activity induced by essential oil of $C$. hystrix peel, which showed a differential chemical composition depending on the origin, need to be investigated in the future. Limonene, the main constituent of tested oil, is also the major component of oils obtained from orange, grapefruit, and lemon. This monocyclic monoterpene has shown chemopreventive and therapeutic activity against a wide variety of experimental tumours ${ }^{39}$. However, cytotoxicity induced by main constituents of essential oil might be related to its complex phytochemical composition and suggest that different components might activate different pathways to execute cell death. A study on bergamot oil engaged to identify the components responsible for cell death induced by the phytocomplex showed that, at comparable concentrations with those found in cytotoxic concentrations of the bergamot oil, none of the tested constituents (limonene, linalyl acetate, linalool, $\gamma$-terpinene, $\beta$-pinene, and bergapten) reduced SH-SY5Y cell viability, while only the combination of limonene and linalyl acetate was able to induce cell death ${ }^{40}$. From the available literature essential oils seem to have a great potential as anticancer therapeutic agents, however, information regarding their mechanism of action is still lacking and far from being deciphered. Indeed, their complex chemical composition makes it difficult to envisage a single mechanism underlying the totality of the biological effect, which is likely the sum and/or synergy of the biological activity of each component. For the same reason, data obtained from single components may not necessarily be, in turn, applied to the whole essential oil. On the other hand, the presence in the phytocomplex of numerous constituents that simultaneously interfere with multiple signalling pathway might be the key for overcoming the current limit of chemotherapeutic agents and in particular the development of multidrug resistance.

\section{REFERENCES}

1. Bakkali F, Averbeck S, Averbeck D, Idaomar M (2008) Biological effects of essential oils-a review. Food Chem Toxicol 46, 446-75.

2. Lianou A, Koutsoumanis KP (2013) Strain variability of the behavior of foodborne bacterial pathogens: a review. Int J Food Microbiol 167, 310-21.

3. Adorjan B, Buchbauer G (2010) Biological properties of essential oils: an updated review. Flavour Frag $J$ 25, 407-26.

4. Aggarwal BB, Shishodia S (2006) Molecular targets of dietary agents for prevention and therapy of cancer. Biochem Pharmacol 71, 1397-421. 
5. Bhalla Y, Gupta VK, Jaitak V (2013) Anticancer activity of essential oils: a review. J Sci Food Agr 93, 3643-53.

6. Reuther W, Webber HJ, Batchelor LD, Batchelor JH, Swingle WT, Reece WT, Hodgson RW, Lawton HW (1967) The Citrus Industry. Revised Edition Univ of California; Division of Agricultural Sciences Vol 1, Chap 3, Subtr 2. Citrinae: Citrus Fruit Trees: websites.lib.ucr.edu/agnic/webber/.

7. Tee ES, Noor MI, Azudin MN, Idris K (1997) Nutrient composition of Malaysian foods, 4th edn, Institute for Medical Research, Kuala Lumpur.

8. Srisukh V, Tribuddharat C, Nukoolkarn V, Bunyapraphatsara N, Chokephaibulkit K, Phoomniyom S, Chuanphung S, Srifuengfung S (2012) Antibacterial activity of essential oils from Citrus hystrix (makrut lime) against respiratory tract pathogens. Sci Asia 38, 212-7.

9. Srisukh V, Bunyapraphatsara N, Pongpan A, Tungrugsasut W, Puttipipatkhachorn S, Oniam W, Karawamitr T, Bunsiriluk S, Thongbainoi W (2012) Fresh produce antibacterial rinse from kaffir lime oil. Mahidol Univ J Pharmaceut Sci 39(2), 15-27.

10. Garnacho-Montero J, Amaya-Villar R (2010) Multiresistant Acinetobacter baumannii infections: epidemiology and management. Curr Opin Infect Dis 23, 332-9.

11. Fitzpatrick MA, Ozer E, Bolon MK, Hauser AR (2015) Influence of ACB complex genospecies on clinical outcomes in a U.S. hospital with high rates of multidrug resistance. $J$ Infect 70, 144-52.

12. Gonzalez-Villoria AM, Valverde-Garduno V (2016) Antibiotic-resistant Acinetobacter baumannii increasing success remains a challenge as a nosocomial pathogen. $J$ Pathog 2016, Article ID 7318075.

13. Magiorakos AP, Srinivasan A, Carey RB, Carmeli Y, Falagas ME, Giske CG, Harbarth S, Hindler JF, et al (2012) Multidrug-resistant, extensively drugresistant and pandrug-resistant bacteria: an international expert proposal for interim standard definitions for acquired resistance. Clin Microbiol Infect 18, 268-81.

14. Buckle J (2015) Clinical Aromatherapy: Essential Oils in Practice, Elsevier, pp 15-36.

15. Manosroi J, Dhumtanom P, Manosroi A (2006) Antiproliferative activity of essential oil extracted from Thai medicinal plants on KB and P388 cell lines. Canc Lett 235, 114-20.

16. Adams RP (2007) Identification of Essential Oil Components by Gas Chromatography/Mass Spectroscopy, 4th edn, Allured Publishing Corporation, Carol Stream, IL.

17. Clinical Laboratory Standards Institute (2008) Performance Standards for Antimicrobial Susceptibility Testing; 18th Informational Supplement, CLSI document M100-S18, National Committee for Clinical Laboratory Standards, Wayne, PA.
18. Woodford N, Ellington MJ, Coelho JM, Turton JF, Ward ME, Brown S, Amyes SG, Livermore DM (2006) Multiplex PCR for genes encoding prevalent OXA carbapenemases in Acinetobacter spp. Int $J$ Antimicrob Agents 27, 351-3.

19. European Committee on Antimicrobial Susceptibility Testing (2015) Disk Diffusion Method for Antimicrobial Susceptibility Testing Version 5.0., www.eucast. org.

20. Clinical Laboratory Standards Institute (2003) Methods for Dilution Antimicrobial Susceptibility Tests for Bacteria that Grow Aerobically, Approved Standard M7-A6, National Committee for Clinical Laboratory Standards, Wayne, PA.

21. Koczurkiewicz P, Podolak I, Wójcik KA, Galanty A, Madeja Z, Michalik M, Czyż J (2013) Lclet 4 enhances pro-apoptotic and anti-invasive effects of mitoxantrone on human prostate cancer cells. Acta Biochim Pol 60, 331-8.

22. Ravenna L, Salvatori L, Morrone S, Lubrano C, Cardillo MR, Sciarra F, Frati L, Di Silverio F, Petrangeli E (2000) Effects of triptorelin, a gonadotropin-releasing hormone agonist, on the human prostatic cell lines PC3 and LNCaP. $J$ Androl 21, 549-57.

23. Hongratanaworakit T, Buchbauer G (2007) Chemical composition and stimulating effect of Citrus hystrix oil on humans. Flavour Frag $J$ 22, 443-9.

24. Sutthanont $\mathrm{N}$, Choochote $\mathrm{W}$, Tuetun $\mathrm{B}$, Junkum A, Jitpakdi A, Chaithong U, Riyong D, Pitasawat B (2009) Chemical composition and larvicidal activity of edible plant-derived essential oils against the pyrethroid-susceptible and -resistant strains of Aedes aegypti (Diptera: Culicidae). J Vector Ecol 35, 106-15.

25. Kasuan N, Muhammad Z, Yusoff Z, Rahiman MHF, Taib MN, Haiyee ZA (2013) Extraction of Citrus hystrix D.C. (kaffir lime) essential oil using automated steam distillation process: Analysis of volatile compounds. Malays J Anal Sci 17, 359-69.

26. Yap PS, Yiap BC, Ping HC, Lim SH (2014) Essential oils, a new horizon in combating bacterial antibiotic resistance. Open Microbiol J 8, 6-14.

27. Gustafson JE, Liew YC, Chew S, Markham JL, Bell HC, Wyllie SG, Warmington JR (1998) Effects of tea tree oil on Escherichia coli. Lett Appl Microbiol 26, 194-8.

28. Helander IM, Alakomi HL, Latva-Kala K, MattilaSandholm T, Pol I, Smid EJ, Gorris LGM, von Wright A (1998) Characterization of the action of selected essential oil components on Gram-negative bacteria. J Agr Food Chem 46, 3590-5.

29. Sikkema J, de Bont JA, Poolman B (1994) Interactions of cyclic hydrocarbons with biological membranes. J Biol Chem 269, 8022-8.

30. Sikkema J, de Bont JA, Poolman B (1995) Mechanisms of membrane toxicity of hydrocarbons. Microbiol Rev 59, 201-22. 
31. Wongsariya K, Phanthong P, Bunyapraphatsara N, Srisukh V, Chomnawang MT (2014) Synergistic interaction and mode of action of Citrus hystrix essential oil against bacteria causing periodontal diseases. Pharmaceut Biol 52, 273-80.

32. Chanthaphon S, Chanthachum S, Hongpattarakere T (2008) Antimicrobial activities of essential oils and crude extracts from tropical Citrus spp. against foodrelated microorganisms. Songklanakarin J Sci Tech 30, 125-31.

33. Nanasombat S, Lohasupthawee P (2005) Antibacterial activity of crude ethanolic extracts and essential oils of spices against Salmonellae and other enterobacteria. KMITL Sci Tech J 5, 527-38.

34. Lertsatitthanakorn P, Taweechaisupapong S, Aromdee C, Khunkitti W (2006) In vitro bioactivities of essential oils used for acne control. Int $J$ Aromather 16, 43-9.

35. Aleksic V, Mimica-Dukic N, Simin N, Nedeljkovic NS, Knezevic P (2014) Synergistic effect of Myrtus communis L. essential oils and conventional antibiotics against multi-drug resistant Acinetobacter baumannii wound isolates. Phytomedicine 21, 1666-74.

36. Sienkiewicz M, Głowacka A, Kowalczyk E, Wiktorowska-Owczarek A, Jóźwiak-Bębenista M, Łysakowska M (2014) The biological activities of cinnamon, geranium and lavender essential oils. Molecules 19, 20929-40.

37. Knezevic P, Aleksic V, Simin N, Svircev E, Petrovic A, Mimica-Dukic N (2016) Antimicrobial activity of Eucalyptus camaldulensis essential oils and their interactions with conventional antimicrobial agents against multi-drug resistant Acinetobacter baumannii. J Ethnopharmacol 178, 125-36.

38. Bardon S, Picard K, Martel P (1998) Monoterpenes inhibit cell growth, cell cycle progression, and cyclin D1 gene expression in human breast cancer cell lines. Nutr Canc 32, 1-7.

39. del Toro-Arreola S, Flores-Torales E, Torres-Lozano C, del Toro-Arreola A, Tostado-Pelayo K, RamirezDueñas MG, Daneri-Navarro A (2005) Effect of D-limonene on immune response in BALB/c mice with lymphoma. Int Immunopharmacol 5, 829-38.

40. Russo R, Ciociaro A, Berliocchi L, Cassiano MGV, Rombolà L, Ragusa S, Bagetta G, Blandini F, Corasaniti MT (2013) Implication of limonene and linalyl acetate in cytotoxicity induced by bergamot essential oil in human neuroblastoma cells. Fitoterapia $\mathbf{8 9}$, 48-57. 